\title{
Intracytoplasmic inclusions in B prolymphocytic leukaemia: ultrastructural, cytochemical, and immunological studies
}

\author{
DSF ROBINSON, JV MELO, C ANDREWS, SA SCHEY, ${ }^{*}$ D CATOVSKY \\ From the Medical Research Centre Leukaemia Unit, Royal Postgraduate Medical School, London, and the \\ ${ }^{*}$ Department of Haematology, Edgware Hospital, Edgware, Middlesex
}

SUMMARY The intracytoplasmic inclusions seen in most cells from a patient with B prolymphocytic leukaemia were analysed using both light and electron microscopy. They consisted of a dense homogeneous structure and were surrounded by a membrane, which had no continuity with the Golgi cisternae or the endoplasmic reticulum; some inclusions had a clear association with small lysosomal granules. Immunofluorescence and immunoperoxidase studies using light microscopy failed to elucidate completely the nature of the inclusions, but immunocytochemical reactions performed using electron microscopy suggested an immunoglobulin nature. All inclusions were negative for acid phosphatase and periodic acid Schiff. The nature of the inclusions described in the prolymphocytes of this patient were compared with those previously recorded in B prolymphocytic leukaemia.

Intracytoplasmic inclusions have been described in neoplastic cells from myelomatosis ${ }^{1-3}$ and in lymphocytes from other B cell malignancies, notably B chronic lymphocytic leukaemia, ${ }^{4-18}$ with an incidence of $5-10 \%$ of cases. ${ }^{81116}$ An even higher incidence has been suggested in B prolymphocytic leukaemia. ${ }^{19-22}$ Since our earlier reports of 18 cases $^{19-21}$ we have studied a further 15 cases of B prolymphocytic leukaemia by electron microscopy, and we document here a new case with unusual inclusions within the cytoplasm.

Several types of inclusion have been described in B cell malignancies. One type consists of an amorphous material that lacks periodicity and is contained within an ergastoplasmic membrane. ${ }^{6} 13141718$ These globular inclusions have the morphological appearance of Russell bodies, and immunofluorescence studies have generally shown them to consist of $\operatorname{IgM} \kappa,^{61417}$ although $\operatorname{IgG} \kappa^{13}$ and $\operatorname{IgM} \lambda^{18}$ have also been described. Another type of inclusion is more common and has a periodicity of $60-100 \AA$, suggestive of a crystalline formation. $246-91112151618$ Pronounced heterogeneity, however, has been noted within this group. Certain inclusions are small needle like structures ${ }^{2}$; others, which have been described as rod shaped or rectangular, ${ }^{46-912151618}$ are generally large and seen as a single structure within the cell. Usually, these are either associated with the Golgi region ${ }^{2519}$ or found within strands of the endoplasmic reticulum. ${ }^{911} 121415$ Immunofluorescence studies have shown that these inclusions consist of immunoglobulin molecules and are predominantly $\lambda$ chains, either alone ${ }^{15}$ or more commonly in association with $\operatorname{IgM}^{6-912151618}$ or IgA. ${ }^{11218} \operatorname{IgM} \kappa$ has been reported once. ${ }^{18}$

The origin of the inclusions so far reported in B prolymphocytic leukaemia is not clear. The structures previously documented by our laboratory were long and needle like in one case and displayed periodicity. ${ }^{20}$ They also showed a variable degree of acid phosphatase reactivity, which suggested a lysosomal origin. ${ }^{20}$ Those described by Kjeldsberg $^{22}$ were multiple and rectangular and also displayed periodicity, but no further analysis into their origin or composition was performed.

We describe another case of B chronic prolymphocytic leukaemia in which most cells contained multiple inclusions that differed from those previously described in either B chronic lymphocytic leukaemia or B cell prolymphocytic leukaemia as they lacked periodicity and, morphologically, did not resemble Russell bodies. Cytochemical and immunological studies, using electron microscopy, 
showed that these inclusions comprised molecules of immunoglobulin, which light microscopy suggested to be $\operatorname{IgM} \kappa$.

\section{CASE REPORT}

A 73 year old man was asymptomatic until two weeks before admission, when he developed difficulties in micturation, intermittent terminal haematuria, and low abdominal pain. On examination he was pale and tachypnoeic at rest and had echymoses on both lower arms and bilateral crepitations and expiratory wheeze over all zones of the chest. There was no lymphadenopathy or hepatomegaly, but the spleen extended across the midline to the right iliac fossa. Investigations showed haemoglobin concentration to be $73 \mathrm{~g} / \mathrm{l}$, platelet count $113 \times 10^{9} / 1$, and white cell count $262.4 \times 10^{\%} / 1$ with $2 \%$ granulocytes and $98 \%$ prolymphocytes. Urea and electrolyte concentrations and results of liver function tests were normal. Prolymphocytic leukaemia was diagnosed. The patient underwent an uneventful transurethral retrograde prostatectomy and subsequently received a total dose of $320 \mathrm{cGy}$ (rads) to the spleen in 11 courses over five weeks. This treatment reduced the size of the spleen to $1 \mathrm{~cm}$ and improved his blood count as follows: haemoglobin concentration $10.3 \mathrm{~g} / \mathrm{l}$, platelets $140 \times 10^{9} / 1$, and white cell count $3.9 \times$ $10^{\%} / 1$ with only $6 \%$ prolymphocytes in the differential count.

\section{Material and methods}

\section{Light microscopy}

Peripheral blood films were stained with MayGrunwald Giemsa for morphological characterisation of the leukaemia cells. The cytochemical reactions for acid phosphatase and periodic acid Schiff ${ }^{23}$ positivity were performed on cytospin slides made from the mononuclear layer. Peripheral blood mononuclear cells were isolated by Lymphoprep (Nyegaard), washed three times in phosphate buffered saline, and finally resuspended in phosphate buffered saline with $0.2 \%$ bovine serum albumin. The following immunological tests were performed: rosette formation with sheep ( $E$ rosettes) and mouse (M rosettes) erythrocytes. ${ }^{24}$ Surface immunoglobulin on cell suspensions and cytoplasmic immunoglobulin on cytospin slides were determined by direct immunofluorescence using fluorescein isothiocyanate conjugated $\mathrm{F}(\mathrm{ab})_{2}$ antibodies (Behring) against heavy $(\mu, \delta, \gamma, \alpha)$ and light $(\kappa, \lambda)$ chains after incubation of mononuclear cells at $37^{\circ} \mathrm{C}$ for two hours to remove cytophilic immunoglobulin.

The presence of cytoplasmic immunoglobulin was also studied on cytospin slides using the method of
Stein with monoclonal antibodies anti- $\mu, \gamma, \alpha, \delta, \kappa$, and $\lambda$ chains (gift of Dr Ling, Birmingham) as primary reagents and horseradish peroxidase conjugated rabbit antimouse and swine antirabbit (Dakopatts) as a second and third layer, respectively. ${ }^{26} \mathrm{~A}$ series of monoclonal antibodies against $\mathrm{B}$ cell antigens were tested by conventional indirect immunofluorescence techniques, using a fluorescein isothiocyanate conjugated $\mathrm{F}(\mathrm{ab})_{2}$ fragment of goat antimouse IgG or IgM (Cappel, Cochranville, Pennsylvania) as a second layer. ${ }^{27}$

\section{Electron microscopy}

Mononuclear cells were fixed in $3 \%$ glutaraldehyde for 30 minutes, washed in phosphate buffered saline, postfixed in osmium tetroxide, and block stained with $4 \%$ uranyl acetate. The cells were preembedded in agar, passed through a series of alcohols, and embedded in Araldite. Serial ultra thin sections were stained with methanolic uranyl acetate and lead citrate and viewed with a Zeiss 10 electron microscope. Acid phosphatase: an adaptation of Gomori's method was used. ${ }^{28}$ The cells were fixed in $1.5 \%$ glutaraldehyde in 0.067 cacodylate buffer $\mathrm{pH}$ 7.4 at $4^{\circ} \mathrm{C}$, then washed three times in $0.1 \mathrm{M}$ cacodylate buffer containing $7.5 \%$ sucrose, and incubated for one hour at $37^{\circ} \mathrm{C}$ in Gomori's medium, Tris maleate buffer containing sodium glycerophosphate as a substrate, and lead nitrate as a coupling agent at $\mathrm{pH} 5 \cdot 0$.

\section{Cytoplasmic immunoglobulins}

An adaptation of the method of Newell et al was

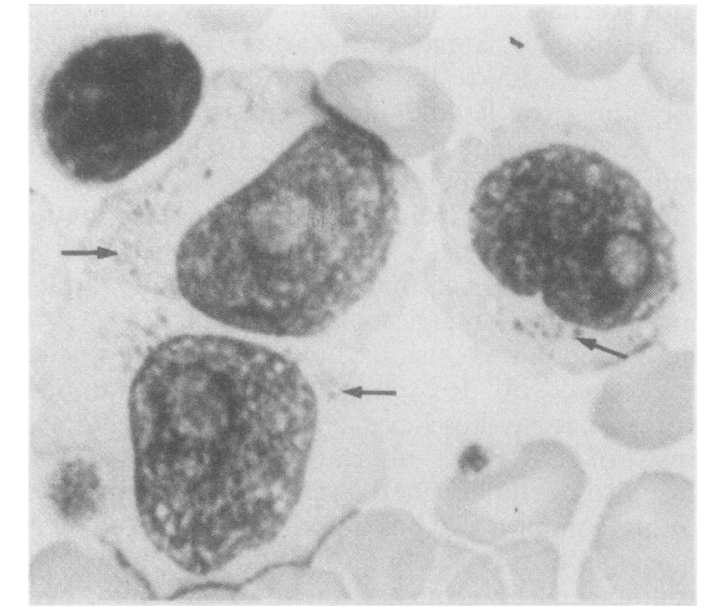

Fig. 1 Peripheral blood prolymphocytes displaying typical features of B prolymphocytic leukaemia: a prominent nucleolus and well condensed chromatin. Numerous granules can be seen scattered throughout cytoplasm (arrows) (May-Grunwald Giemsa stain.) × 1500 . 
Membrane phenotype of peripheral blood cells

\begin{tabular}{|c|c|c|c|}
\hline Test & Reactivity & Reference & Result (\%) \\
\hline $\begin{array}{l}\text { E rosettes } \\
\text { Mouse rosettes }\end{array}$ & \multirow{6}{*}{$\begin{array}{l}\text { T cells } \\
\text { B chronic lymphocytic leukaemia } \\
\text { B lymphocytes }\end{array}$} & \multirow{6}{*}{$\begin{array}{l}(24) \\
(25)\end{array}$} & 2 \\
\hline $\begin{array}{l}\text { Mouse rosettes } \\
\text { SmIg: }\end{array}$ & & & \\
\hline IgM & & & $97+++$ \\
\hline IgD & & & $93++$ \\
\hline Kappa & & & $98++$ \\
\hline $\operatorname{IgA}$ IgG. lambda & & & Negative \\
\hline Cytoplasmic immunoglobulin: & \multirow[t]{2}{*}{ B lymphocytes and plasma cells } & & \\
\hline $\begin{array}{l}\text { IgM, kappa } \\
\text { IgA, IgD, IgG, lambda }\end{array}$ & & & $\begin{array}{l}90 \\
\text { Negative }\end{array}$ \\
\hline Monoclonal antibodies: & & & \\
\hline FMC4 & \multirow{2}{*}{$\begin{array}{l}\text { Class II major histocompatibility complex antigents } \\
\text { Proportion of normal B and majority of } \\
\text { B prolymphocytic leukaemia }\end{array}$} & (31) & 95 \\
\hline FMC7 & & (32) & 98 \\
\hline J5 & B cells (gp100) & (33) & 96 \\
\hline OKT10 & Activated $B$ and $T$ cells & (34) & 3 \\
\hline Tac & IL2 receptor & $(35,36)$ & 4 \\
\hline $\begin{array}{l}\mathrm{UCHT} 2 \\
\mathrm{HC} 1, \mathrm{HC} 2\end{array}$ & $\begin{array}{l}\text { T cells; anti-p67 } \\
\text { Antihairy cells }\end{array}$ & $\left(\begin{array}{l}37) \\
38\end{array}\right)$ & $\begin{array}{l}\text { Negative } \\
\text { Negative }\end{array}$ \\
\hline
\end{tabular}

used. ${ }^{29}$ The cells were fixed in $0 \cdot 1 \%$ glutaraldehyde for 15 minutes, washed in phosphate buffered saline and treated with $1 \%$ saponin (Sigma) for seven minutes at $55^{\circ} \mathrm{C}$. The cells were then washed three times in phosphate buffered saline and incubated with horseradish peroxidase conjugated rabbit antihuman $\mathrm{Ig}$ at a concentration of $1: 15$ for one hour at room temperature. The pellet was then washed and the peroxidase developed using the technique of Graham and Karnovsky. ${ }^{30}$ The postfixation was done in $3 \%$ glutaraldehyde for 30 minutes and the electron microscopy procedure continued as described above. Test antiserum consisted of horseradish peroxidase conjugated antihuman immunoglobulin (Dakopatts), and horseradish peroxidase conjugated antihuman IgG was used as a control. No counterstaining was performed when viewing the acid phosphatase or cytoplasmic immunoglobulin reactions.

\section{Results}

\section{Light microscopy}

Most peripheral blood cells had the typical mor-

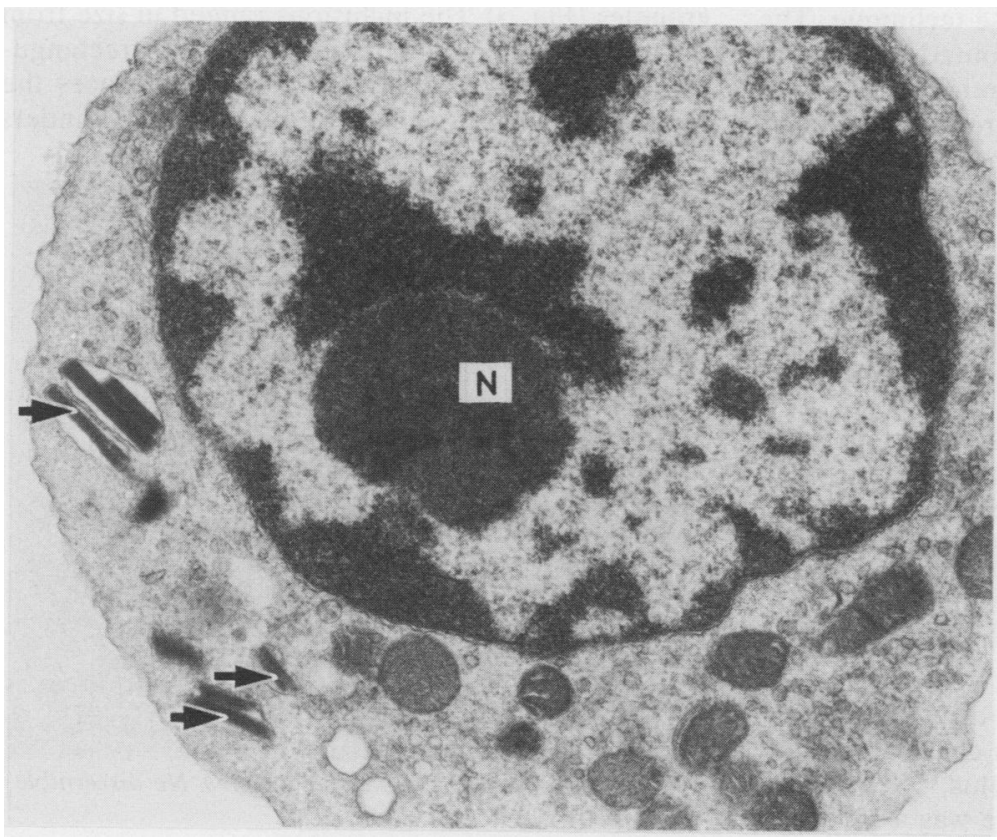

Fig. 2 Ultrastructure of prolymphocyte with prominent nucleolus $(N)$. Several rod shaped electron dense inclusions may be seen in the cytoplasm (arrows). $\times 16000$. Sections of Figs. 2-4 are block stained with $4 \%$ uranyl acetate. 


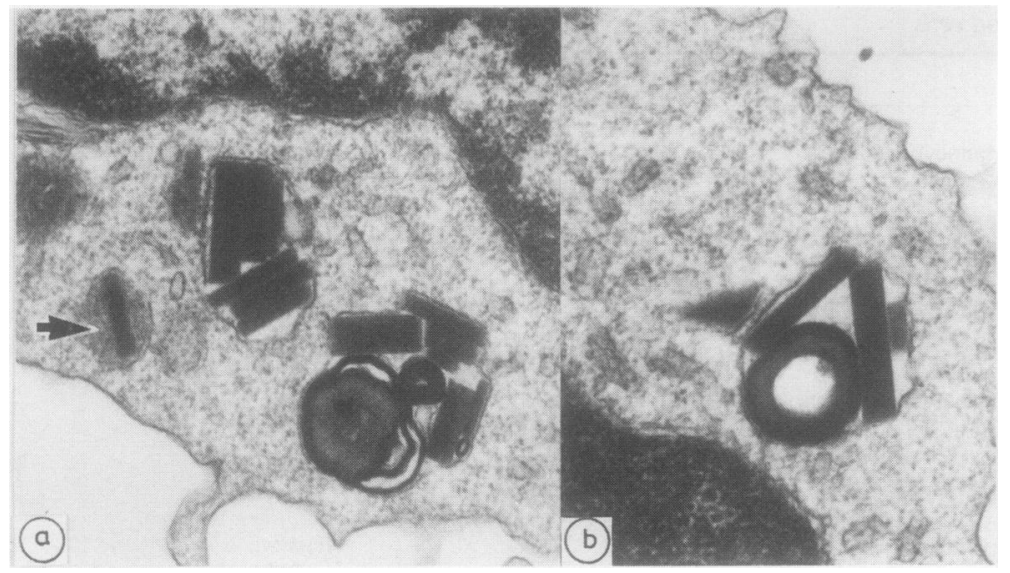

Fig. 3 (a) Numerous inclusions may be seen contained within a single membrane. Occasionally, an inclusion was seen to bisect a lysosomal granule (arrow). $\times 30$ 000. (b) Inclusion distorted into hollow cylinder. $\times$ 32000.

phology of prolymphocytes with a prominent nucleolus and well condensed chromatin (Fig. 1). Almost all of these cells $(90 \%)$ had several azurophilic granules in the cytoplasm. These were mainly localised in the perinuclear area, but in some cases they were more widely distributed throughout the cytoplasm.

The Table summarises the immunological phenotype of these cells. Their B cell nature was shown by the strong expression of $\operatorname{IgM} / \operatorname{IgD} \kappa$ and class II human leucocyte antigen determinants. Cytoplasmic $\mu$ and $\kappa$ chains were shown in most prolymphocytes, but the analysis of their localisation could be better appreciated in cytospin slides stained by means of the immunoperoxidase technique. The reaction in these was evenly distributed throughout the cytoplasm with an accentuation in the region of the surface membrane. The azurophilic granules observed in May-Grunwald Giemsa stained slides could not be visualised in these preparations; instead, multiple vacuoles were seen, displaying strong reactivity for both $\mu$ and $\kappa$ chains in their periphery but without any internal reactivity. The localisation and distribution of these vacuoles corresponded to that of the granules seen in the MayGrunwald Giemsa stained slides.

The prolymphocytes were negative for periodic acid Schiff and showed no important acid phosphatase reactivity, although certain cells were weakly positive with a diffuse reaction product. The inclusions failed to stain and showed a weak positivity reaction in their periphery.

\section{Electron microscopy}

Ninety five per cent of the cells displayed typical features of prolymphocytes with a characteristically prominent, often ring form, nucleolus; ${ }^{19} 5 \%$ showed the features of plasma cells. There was a moderate degree of chromatin condensation with clumping of the heterochromatin in the vicinity of the nucleolus. The Golgi apparatus was poorly developed, and all the cells had only limited profiles of endoplasmic reticulum. Most cells contained a variable number (1-36/cell section) of localised electron dense inclusions, which, invariably, were surrounded by a membrane (Fig. 2). Often several inclusions of different sizes were surrounded by the same membrane, which did not appear to have any association with Golgi cisternae or the endoplasmic reticulum.

The inclusions were seen in close association with small, medium density granules in $40 \%$ of cells; in some cells the inclusions seemed to have divided the granules (Fig. 3) The inclusions ranged in size from 0.2 to $0.6 \mu \mathrm{m}$ in length. They were mainly rectangular or rod shaped, although in some instances the rod shaped inclusions had formed hollow cylinders

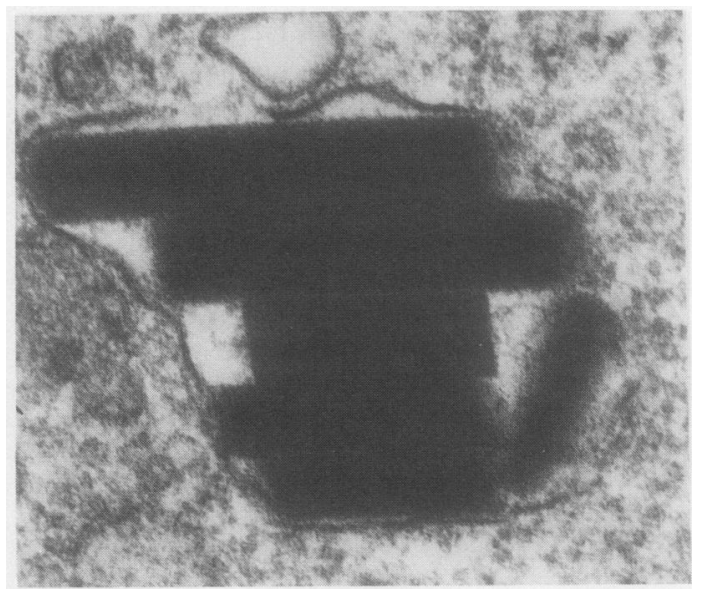

Fig. 4 High magnification of inclusions. No discernible periodicity was evident. $\times 73500$. 


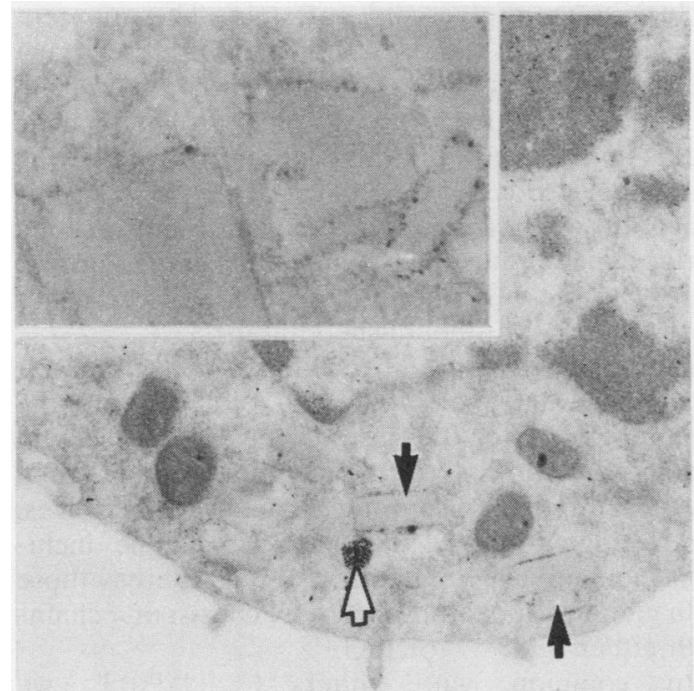

Fig. 5 Cell showing acid phosphatase negativity of inclusions (arrows). Note that periphery of inclusions is acid phosphatase positive as is adjacent lysosomal granule (white arrow). $\times 17$ 600. Inset shows higher magnification of negative inclusions and acid phosphatase reactivity. $\times$ 40000.

(Fig. 3). No discernible periodicity within any of the inclusions was noted, even at very high magnification (Fig. 4).

The acid phosphatase reaction at electron microscopy confirmed the findings of light microscopy, showing that the inclusions were negative except at their periphery, where they seemed to be slightly positive. The granules that were often seen in association with the inclusions also showed acid phosphatase reactivity (Fig. 5).

Variable reactivity of the inclusions with antihuman polyvalent Ig was observed. In many instances the inclusions and the surrounding membranes were clearly positive (Fig. 6a). In some cells, however, the reactivity was confined to the edge of the inclusion, the core remaining unreactive. Possibly, this partial reactivity may indicate poor penetration of the reagent. No inclusion or membranous structures were seen as positive when antihuman IgG was used as a control (Fig. 6b).

Fig. 6 (a) Cell reactive with antihuman Ig (polyvalent antibody). Note reactivity of cell membrane and inclusions (arrow). Occasional inclusions failed to react (white arrow). $\times 17000$. Inset shows higher magnification of reactive inclusion. $\times 40000$.

(b) Cell from control sample using antihuman IgG. No reactivity is apparent either on surface membrane or within inclusion. $\times 21000$. Inset shows higher magnification of non-reactive inclusion. $\times 40000$.

Cells from Figs. 5 and 6 were viewed unstained.
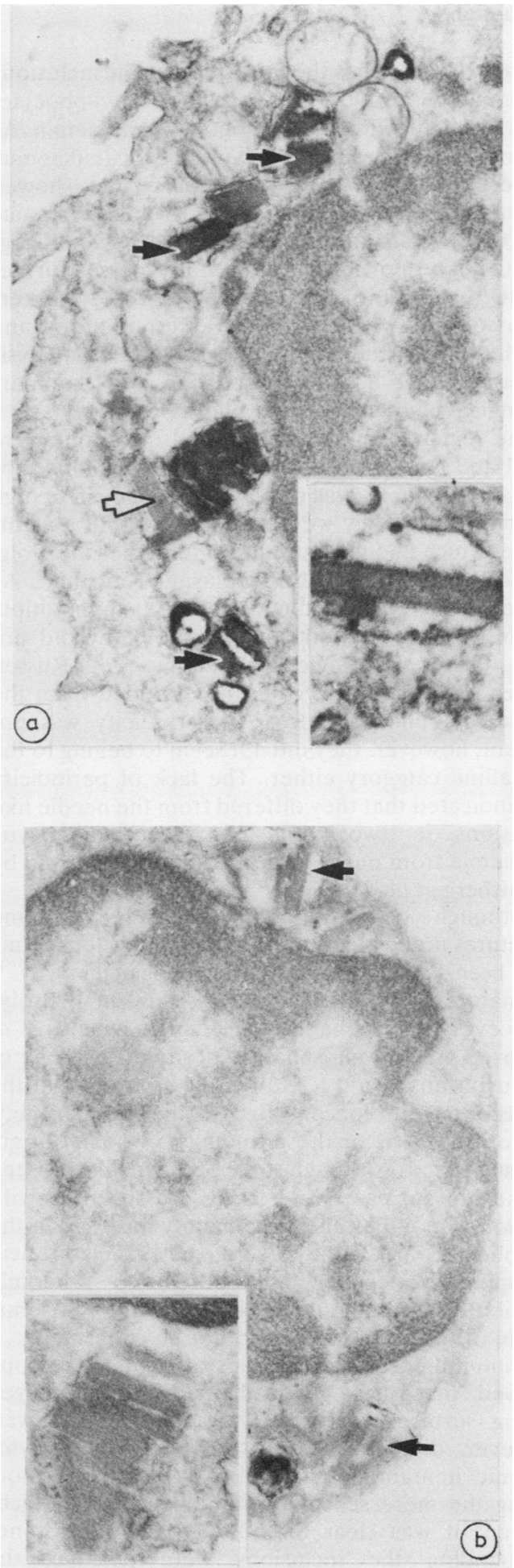


\section{Discussion}

This report describes the intracytoplasmic inclusions contained within $90 \%$ of typical B prolymphocytes from a patient with B prolymphocytic leukaemia. As in most other cases of B prolymphocytic leukaemia, the cells were positive with FMC7 and showed strong expression of SmIg. ${ }^{39}$ The reactivity of some cells with OKT10 and antiTac (Table 1) would suggest that a proportion of cells had progressed further in the $B$ differentiation pathway as these markers are associated with plasma cell differentation ${ }^{34}$ and cellular activation. ${ }^{35}$ Ultrastructural analysis confirmed that a small proportion had the morphological characteristics of plasma cells.

The rectangular and rod shaped inclusions were small and composed of a dense homogeneous substance. Periodicity was never observed, even at high magnification. They were contained within a membrane, which had no continuity with either the Golgi apparatus or strands of endoplasmic reticulum. As the inclusions were rectangular, dense, and multiple within each surrounding membrane, they did not have the morphological appearance of Russell bodies and, therefore, could be excluded from the typical globular category. As periodicity was not evident, however, they did not seem to belong to the crystalline category either. The lack of periodicity also indicated that they differed from the needle like inclusions in two cases of B prolymphocytic leukaemia from our laboratory and one reported by Kjeldsberg et al. ${ }^{20-22}$

Although both the globular and crystalline structures noted in B chronic lymphocytic leukaemia have been shown to consist of immunoglobulin, ${ }^{6-9}$ 12-18 $^{-18}$ the nature of the inclusions described in B prolymphocytic leukaemia is uncertain. Costello et al reported an acid phosphatase positivity of some of the inclusions, ${ }^{20}$ and Kjeldsberg et al noted that the inclusions were concentrated in the Golgi zone, ${ }^{22}$ and on the basis of those findings a lysomal origin was suggested. Although some of the inclusions seen in the present case were in close association with lysosomal granules and were mainly localised in the perinuclear area, they were, nevertheless, acid phosphatase negative and were also randomly distributed throughout the cell. Thus the lysosomal origin of the inclusions could not be confirmed.

Immunofluorescence studies at light microscopy showed that these B prolymphocytes displayed strong surface reactivity with anti-IgMk. It was, however, difficult to show the presence of cytoplasmic immunoglobulin reliably by this method. Using the more sensitive immunoperoxidase technique, ${ }^{26}$ it was clear that though the membranes surrounding the inclusions were positive, the inclusions themselves did not stain. The apparent non-reactivity of the inclusions may have been due to the sensitivity of such structures to certain fixatives. ${ }^{2}$ In four other cases of B prolymphocytic leukaemia tested in this laboratory with the immunoperoxidase technique the cytoplasmic reaction was diffuse, with enhancement on the surface membrane, and, unlike the case reported here, vacuoles with peripheral staining were never observed, (JVM, unpublished findings).

Immunocytochemical reactions performed at ultrastructural level, however, did confirm the immunoglobulin nature of the inclusions. Reactivity was localised not only in the membrane surrounding the structures but also in the structures themselves. Interestingly, most documented crystalline inclusions contain $\lambda$ light chain, ${ }^{6911121618}$ whereas those with globular appearance (type 1) consist of $\kappa$ chains with either $\operatorname{IgM}^{614}{ }^{17}$ or IgG. ${ }^{13}$

In common with others $2469-1115161820$ we observed that the inclusions were negative for periodic acid Schiff. These findings and more recent biosynthetic studies ${ }^{14}$ have led to the hypothesis that the immunoglobulin contained within both the crystalline and globular inclusions represents an accumulation of molecules that results from an aberrant secretory mechanism, more specifically from an inadequate addition of carbohydrate. ${ }^{711} 1314$ Although evidence in the present case is far from conclusive, we are tempted to speculate that the inclusions described here may be a result of a similar kind of defect.

JVM was supported by a grant from CAPES, Brazil. We thank Dr Ling, Birmingham, for the gift of monoclonal antibodies against human Ig.

\section{References}

'Neuman V. Multiple plasma cell myeloma with crystalline deposits in the tumour cells and in the kidneys. Journal of Clinical Bacteriology 1949;61:165-9.

${ }^{2}$ Stavem P, Vandik B, Skrede S, Hovig T. Needle-like crystals in plasma cells in a patient with a plasma cell proliferative disorder. Scand J Haematatol 1975;14:24-34.

${ }^{3}$ Nakamine H, Nishihara T, Saito K, Takenaka T, Maeda J. Needle-shaped inclusions in plasma cells in a patient with hypogammaglobulinemia. Am J Clin Pathol 1982;78:549-55.

${ }^{4}$ de Man JCH, Meiners WBH. Crystals of protein nature in the cytoplasm of lymphatic cells in a case of lymphoreticular malignancy. Blood 1962;20:492-500.

' Laszlo J, Gerber HJ, Sommer JR. Composition and structure of cytoplasmic globules in leukemic lymphocytes. Blood 1967;29:77-86.

- Hurez D, Flandrin G, Preud'homme JL, Seligmann M. Unreleased intracellular monoclonal macroglobulin in chronic lymphocytic leukaemia. Clin Exp Immunol 1972;10:223-34.

' Kaplan ME, Clark C, Rydell RE. Crystalline IgM inclusions in CLL lymphocytes. Clinical Research 1972;20:787. 
' Preud' homme JL, Seligmann M. Surface bound immunoglobulin as cell marker in human lymphoproliferative diseases. Blood 1972; 40:777-94.

' Clark AC, Rydell RE, Kaplan ME. Frequent association of IgM with crystalline inclusions in chronic lymphatic leukemic lymphocytes. N Engl J Med 1973;289:113-7.

${ }^{10}$ Lagios MD, Freidlander LM, Wallerstein RO, et al. Atypical azurophilic crystals in chronic lymphocytic leukemia. A case report and comparison with other crystalline inclusions. Am J Clin Pathol 1974;62:342-9.

"Cawley JC, Barker CR, Britchford RD, Smith JL. Intracellular IgA immunoglobulin crystals in chronic lymphocytic leukaemia. Clin Exp Immunol 1973;13:407-16.

${ }^{12}$ Cawley JC, Smith J, Goldstone AH, et al. IgA and IgM cytoplasmic inclusions in a series of cases of chronic lymphocytic leukaemia. Clin Exp Immunol 1976;23:78-82.

${ }^{13}$ Nies KM, Marshall J, Oberlin A, et al. Chronic lymphocytic leukemia with gamma chain cytoplasmic inclusions. Am J Clin Pathol 1976;65: 948-56.

${ }^{14}$ Smith JL, Gordon J, Newell DG, Whisson M. The biosynthesis and characterisation of unreleased IgM in a case of CLL. Br J Haematol 1977;37:217-22.

is McCann SR, Wheelan A, Greally J. Intracellular chain inclusions in chronic lymphocytic leukaemia. $\mathrm{Br} J$ Haematol 1978;38:367-71.

10 Roberts GH, Gordon J, Smith JL, et al. Biosynthesis and characterisation of IgMk in a case of chronic lymphocytic leukaemia with intracellular immunoglobulin inclusions. J Clin Pathol 1979; 32: 272-9.

${ }^{17}$ Guglielmi P, Preud'homme JL, Gourdin MF, et al. Unusual intracytoplasmic immunoglobulin inclusions in chronic lymphocytic leukaemia. Br J Haematol 1982;50:1233-4.

${ }^{18}$ Peters O, Thielemans C, Steenssens L, et al. Intracellular inclusion bodies in 14 patients with $\mathrm{B}$ cell lymphoproliferative disorders. J Clin Pathol 1984;37:45-50.

${ }^{19}$ Costello C, Catovsky D, O'Brien M, Galton DAG. Prolymphocytic leukaemia: an ultrastructural study of 22 cases. $\mathrm{Br} \mathrm{J}$ Haematol 1980;44:389-94.

${ }^{20}$ Costello C, Catovsky D, O' Brien M. Cytoplasmic inclusions in a case of prolymphocytic leukemia. Am J Clin Pathol 1981;76:499-501.

${ }^{21}$ Catovsky D, Matutes E, Crockard AD, O'Brien M, Costello C. Prolymphocytic leukemia of $B$ and $T$ cell types: morphological differences by light and electron microscopy. In: Polliack A. ed. Human leukemias: cytochemical and ultrastructural techniques in diagnosis and research. Boston: Martinus Nijhoff, 1984:251-9.

${ }^{22}$ Kjeldsberg CR, Bearman RM, Rappaport H. Prolymphocytic leukemia: an ultrastructural study. $\mathrm{Am} J$ Clin Pathol 1980;73: 150-9.

${ }^{23}$ Dacie JV, Lewis SM. Practical haematology, 6th ed. Edinburgh: Churchill Livingstone, 1984.

${ }^{24}$ Stathopoulos G, Elliott EV. Formation of mouse or sheep red blood cell rosettes by lymphocytes from normal and leukaemic individuals. Lancet 1974; i: 600-1.

${ }^{2 s}$ Cherchi M, Catovsky D. Mouse RBC rosettes in chronic lymphocytic leukaemia different expression in blood and tissues. Clin Exp Immunol 1980;39:411-15.
${ }^{26}$ Stein H, Gerdes J, Schwab W, et al. Identification of Hodgkin and Sternberg-Reed cells as a unique cell type derived from a newly detected small cell population. Int $J$ Cancer 1982;30:445-9.

${ }^{27}$ Brito-Babapulle V, Melo JV, Foroni L, et al. Neoplastic $\kappa$ and $\lambda$ cells in B-PLL with chromosome translocations of both light chain gene regions. Int $J$ Cancer 1984;34:769-73.

${ }^{28}$ Barka T, Anderson PJ. Histochemical methods for acid phosphatase using hexazonium pararosanilin as a coupler. $J$ Histochem Cytochem 1962;10:741-53.

${ }^{24}$ Newell DG, Bohane C, Payne S, Smith JL. The intracellular localisation of immunoglobulin in human lymphoid cells and haematopoietic cell lines by immunoperoxidase electron microscopy. J Immunol Methods 1980;37:275-86.

${ }^{30}$ Graham RC, Karnovsky MJ. The early stages of absorption of injected horseradish peroxidase in the proximal tubules of mouse kidney: ultrastructural cytochemistry by a new technique. J Histochem Cytochem 1966;14:291-302.

${ }^{31}$ Beckman IGR, Bradley J, Brooks DA, et al. Human lymphocyte markers defined by antibodies derived from somatic cell hybrids. II. A hybridoma secreting antibody against an antigen expressed by human B and null lymphocytes. Clin Exp Immunol 1980;40:593-601.

${ }^{32}$ Brooks DA, Beckman IGR, Bradley J, McNamara PJ, Thomas ME, Zola H. Human lymphocyte markers defined by antibodies derived from somatic cell hybrids. IV. A monoclonal antibody reacting specifically with a subpopulation of human B lymphocytes. J Immunol 1981;126:1373-7.

${ }^{33}$ Ritz J, Pesando JM, Notis-McConarty J, Lazarus H, Schlossman SF. A monoclonal antibody to human acute lymphoblastic leukemia antigen. Nature $1980 ; 283$ :583-5.

${ }_{34}$ Van Camp B, Thielemans C, Dehou MF, de Mey J, de Waele M. Two monoclonal antibodies (OKla1 and OKT10) for the study of the final B cell maturation. J Clin Immunol 1982;2 (suppl):675-745.

${ }^{35}$ Korsmeyer SJ, Greene WC, Cossman J, et al. Rearrangement and expression of immunoglobulin genes and expression of TAC antigen in hairy cell leukemia. Proc Natl Acad Sci USA 1983;80:4522-6.

${ }^{36}$ Robb RJ, Greene WC. Direct demonstration of the identity of T cell growth factor-binding protein and the TAC antigen.J Exp Med 1983;158: 1332-7.

${ }^{37}$ Linch DC. Beverley PCL, Newland A, Turnbull A. Treatment of a low grade T-cell proliferation with monoclonal antibody. Clin Exp Immunol 1983;51:133-40.

${ }^{38}$ Posnett DN, Chiorazzi N, Kunkel HG. Monoclonal antibodies with specificity for hairy cell leukemia cells. J Clin Invest 1982;70: 254-61.

${ }^{34}$ Catovsky D, Cherchi M, Brooks D, Bradley J, Zola H. Heterogeneity of B-cell leukemias demonstrated by the monoclonal antibody FMC7. Blood 1981;58:406-8.

Requests for reprints to: Dr D Catovsky, Medical Research Centre, Leukaemia Unit, Royal Postgraduate Medical School, Hammersmith Hospital, Ducane Road, London W12 0HS, England. 